J. Dairy Sci. 92:4805-4811

doi:10.3168/jds.2009-2237

(c) American Dairy Science Association, 2009.

\title{
Nisin and lacticin 481 coproduction by Lactococcus lactis strains isolated from raw ewes' milk
}

\author{
D. Bravo, E. Rodríguez, and M. Medina ${ }^{1}$ \\ Departamento Tecnología de Alimentos, Instituto Nacional de Investigación y Tecnología Agraria y Alimentaria (INIA), \\ Carretera de La Coruña km 7, 28040 Madrid, Spain
}

\begin{abstract}
Bacteriocin-producing lactococci were isolated from raw ewes' milk samples obtained from 5 different Protected Designation of Origin Zamorano cheese manufacturers. Thirteen isolates with antimicrobial activity against Lactococcus lactis HP were selected. Eleven were identified by a PCR technique as L. lactis ssp. lactis and 2 were identified as L. lactis ssp. cremoris. They were grouped under 4 different pulsed-field gel electrophoresis patterns. The presence of structural genes of both nisin and lacticin 481 was detected in 10 L. lactis ssp. lactis isolates belonging to 2 different pulsed-field gel electrophoresis patterns. Coproduction of nisin and lacticin 481 was confirmed after semipurification by using selective indicators. The production of 2 bacteriocins by the same strain is an uncommon property, with relevance in food safety. Nisin and lacticin 481 L. lactis-producing strains might be used as adjunct cultures to the commercial starter in the manufacture of dairy products.
\end{abstract}

Key words: lactococcus, nisin, lacticin 481, raw ewes' milk

\section{INTRODUCTION}

Lactococcus lactis strains are used as starter cultures in the manufacture of cheese. The isolation and characterization of lactococci from dairy products manufactured by using traditional procedures, without added commercial starters, to extend the availability of cultures has been considered in the search for industrially important properties (Cogan et al., 1997). On the other hand, the demand for safe foods with a prolonged shelf life and minimal processing technologies has considerably enhanced the interest in biopreservation. Raw milk products represent a source of new strains of lactic acid bacteria (LAB) with the potential to inhibit

Received March 24, 2009.

Accepted July 2, 2009.

${ }^{1}$ Corresponding author: mmedina@inia.es undesirable microbiota (Cogan et al., 1997; Rodriguez et al., 2000).

Many LAB produce bacteriocins, ribosomally synthesized antibacterial peptides with activity against related species (Cleveland et al., 2001). Although many bacteriocins from $\mathrm{LAB}$ have been characterized and exhibit a large spectrum of food applications, the lantibiotic nisin is the only bacteriocin industrially exploited as a food preservative. The potential applications for other lactococcal lantibiotics have been reviewed by Guinane et al. (2005), mainly focusing on the 2-component lacticin 3147 and its activity to control nonstarter LAB and accelerate cheese ripening and as food biopreservative. The properties of lacticin 481 have recently been reviewed by Dufour et al. (2007). Lacticin 481 has been used successfully in flavor enhancement, in the acceleration of cheese ripening (Oumer et al., 2001; Garde et al., 2006), and, combined with high pressure, in the reduction of pathogen levels in cheese (Rodriguez et al., 2005).

The application of bacteriocins in foods would allow a significant reduction in the concentration of additives, the intensity of physical treatments currently applied in food manufacture, or both. However, their use is limited by the proteolytic activity of food enzymes, by their adsorption onto fat in foods, and by the appearance of resistant variants in sensitive strains. The potential emergence of resistant populations could be counteracted by the use of LAB that produce multiple bacteriocins (Deegan et al., 2006) because bacteriocins in combination may overcome these shortcomings (Hanlin et al., 1993).

The development of bacterial strains exhibiting overexpression of bacteriocins by genetic manipulation and the introduction of this characteristic into different organisms have received particular attention (Settanni and Corsetti, 2008), although the application of these technologies would be limited by restrictive legal regulations and the lack of acceptance by consumers. Transconjugant lactococcal starters coproducing 2 lantibiotics, lacticin 481 and the 2-component lacticin 3147, were constructed by O'Sullivan et al. (2003). On the other hand, natural multiple-bacteriocin produc- 
tion has been reported for some LAB. Nonlantibiotic multiple-bacteriocin production has been described for Carnobacterium piscicola LV17, which produces 3 carnobacteriocins (Quadri et al., 1994), or Enterococcus faecium L50, which produces 3 different enterocins (Cintas et al., 2000). Garde et al. (2001) detected the genetic determinants of nisin $\mathrm{Z}$ and lacticin 481 in a $L$. lactis ssp. lactis isolate from Manchego cheese.

In the present work, based on previous results concerning multiple-bacteriocin production, our main objective was to study the production of nisin and lacticin 481 by wild lactococci isolated from raw ewes' milk used in the manufacture of Protected Designation of Origin (PDO) Zamorano cheese, made in central Spain without added starter cultures.

\section{MATERIALS AND METHODS}

\section{Isolation of Bacteriocin-Producing Bacteria}

Bacterial strains were isolated from raw ewes' milk obtained from 5 different manufacturing plants producing PDO Zamorano cheese. Refrigerated $\left(4\right.$ to $6^{\circ} \mathrm{C}$ ) bulk ewes' milk samples $(500 \mathrm{~mL}$ ) from mixed evening and morning milkings were collected approximately 2 to $3 \mathrm{~h}$ after the morning milking and transported to the laboratory at $4^{\circ} \mathrm{C}$. Curds from 2 milk samples per plant were prepared upon arrival under aseptic conditions to enrich them for LAB. Rennet (Maxiren 15L, Gist Brocades NV, Delft, the Netherlands) was added to $200 \mathrm{~mL}$ of milk at $30^{\circ} \mathrm{C}$. Curds were cut 40 min after rennet addition, drained, and held at $25^{\circ} \mathrm{C}$ for $18 \mathrm{~h}$. Curd samples $(10 \mathrm{~g})$ were homogenized in 90 $\mathrm{mL}$ of sterile $2 \%$ sodium citrate solutions, and decimal dilutions in peptone $(0.1 \%)$ water were inoculated on the surface of de Man, Rogosa, Sharpe (MRS) agar plates (Difco Laboratories, Detroit, MI) with 2\% (wt/ vol) $\beta$-glycerophosphate (Merck, Darmstadt, Germany) by using an Spiral system (Interscience, Saint Nom La Brèteche, France). Duplicated plates were incubated at $30^{\circ} \mathrm{C}$ for $48 \mathrm{~h}$ and then overlaid with $3 \mathrm{~mL}$ of APT broth (Difco) with $0.75 \%$ (wt/vol) agar inoculated with $0.1 \mathrm{~mL}$ of an 18-h culture in APT broth of L. lactis ssp. cremoris HP. After $24 \mathrm{~h}$ of incubation at $30^{\circ} \mathrm{C}$, colonies surrounded by clear inhibition areas were isolated. They were maintained at $-80^{\circ} \mathrm{C}$ as stock cultures in MRS broth supplemented with $30 \%$ (wt/vol) glycerol until further characterization and were activated by 2 successive transfers before use.

Antimicrobial activity of the isolates was confirmed by the agar well diffusion assay (Schillinger and Lücke, 1989). Neutralized supernatants $(25 \mu \mathrm{L})$ from cultures grown in MRS broth were filtered (Millex GV, Millipore, Bedford, MA) and placed in triplicate into wells made in plates seeded with an overnight culture of $L$. lactis HP or Lactobacillus buchneri St2A. Plates were incubated at 30 or $37^{\circ} \mathrm{C}$, respectively, and examined for the presence of zones of growth inhibition.

\section{Genotypic Characterization of Lactococcus spp.}

Isolates showing inhibition against L. lactis HP were purified on MRS agar plates by several transfers. Grampositive and catalase-negative cocci were identified by the PCR-based technique of Beimfohr et al. (1997) by using 3 pairs of primers complementary to the histidine biosynthesis operon of L. lactis. Genomic DNA was prepared from 2 colonies of each isolate grown on MRS agar. Colonies were suspended in $20 \mu \mathrm{L}$ of sterile double-distilled water in microcentrifuge tubes, mixed gently, and heated at $85^{\circ} \mathrm{C}$ for $10 \mathrm{~min}$. This preparation was used as a template. Amplification was carried out in a Gene ATAQ Controller thermal reactor (Pharmacia LKB Biotechnology AB, Uppsala, Sweden) as described by Beimfohr et al. (1997).

\section{Pulsed-Field Gel Electrophoresis Typing}

Strain characterization was carried out by means of pulsed-field gel electrophoresis (PFGE), according to a modification of the method of Le Bourgeois et al. (1989). Genomic DNA was prepared in agarose blocks and treated with $S m a \mathrm{I}$ (30 IU) restriction endonuclease (New England Biolabs, Ipswich, MA). Electrophoresis was carried out at $14^{\circ} \mathrm{C}$ in a Chef DRII apparatus (BioRad Laboratories, Madrid, Spain) in a $1 \%$ agarose gel containing $0.5 \times$ Tris, borate, EDTA buffer at $6 \mathrm{~V} / \mathrm{cm}$ at 1 to $5 \mathrm{~s}$, with a linear increase over $22 \mathrm{~h}$. The gels were stained in ethidium bromide solution $(0.5 \mu \mathrm{g} / \mathrm{mL})$ and analyzed by using the Diversity Database program (Bio-Rad Laboratories). The similarity of the band profiles was calculated by means of the Dice coefficient and clustered by the unweighted pair group method with arithmetic mean.

\section{Characterization of Bacteriocins}

Polymerase chain reaction amplification to detect the structural genes of nisin, lacticin 481, and lactococcin A was carried out with the primers and conditions indicated by Rodriguez et al. (2000). Reaction parameters were $92^{\circ} \mathrm{C}$ for $2 \mathrm{~min}, 41^{\circ} \mathrm{C}$ for $2 \mathrm{~min}$, and $72^{\circ} \mathrm{C}$ for 2 min, for a total of 26 cycles for nisin primers; $92^{\circ} \mathrm{C}$ for $30 \mathrm{~s}, 51^{\circ} \mathrm{C}$ for $30 \mathrm{~s}$, and $72^{\circ} \mathrm{C}$ for $1 \mathrm{~min}$, for a total of 26 cycles for lacticin 481 primers; and $92^{\circ} \mathrm{C}$ for $2 \mathrm{~min}$, $38^{\circ} \mathrm{C}$ for $2 \mathrm{~min}$, and $72^{\circ} \mathrm{C}$ for $2 \mathrm{~min}$, for a total of 30 cycles for lactococcin A primers. Amplified bands were visualized on $1 \%$ agarose gels by ethidium bromide 
staining by using a 100-bp ladder (Gibco BRL, Life Technologies Inc., Gaithersburg, MD) as the molecular weight standard.

The PCR-generated fragments with the primers for nisin and lacticin 481 were extracted from agarose gels and purified with a QIAquick PCR purification kit (Qiagen, Crawley, UK) according with the instructions of the supplier. Purified PCR fragments were sequenced by using the ABI Prism Big Dye Terminator Cycle Sequencing Ready Reaction Kit (Perkin-Elmer, Waltham, MA). The sequences were compared with the Basic Local Alignment Search Tool programs of the National Center for Biotechnology Information.

Nisin A-producing L. lactis ssp. lactis ATCC 11454, lacticin 481 producing L. lactis ssp. lactis CNRZ 481, and lactococcin A producing L. lactis ssp. lactis WM4, as well as L. lactis ssp. lactis INIA 626 producing nisin Z, L. lactis ssp. lactis INIA 639 producing lacticin 481, and L. lactis ssp. lactis INIA 415 with the genetic determinants of both nisin Z and lacticin 481, from the INIA Culture Collection, were used as positive controls for bacteriocin characterization. Lactococcus lactis $\mathrm{HP}$ was used as a negative control for bacteriocin production. Lactococcus lactis HP sensitive to nisin and lacticin 481, and $L b$. buchneri St2A sensitive to nisin and resistant to lacticin 481 were used as selective indicators.

\section{SDS-PAGE Analysis}

Tricine SDS-PAGE (Schägger and von Jagow, 1987) was performed by using a miniVE system (Hoefer Inc., San Francisco, CA). After electrophoresis, the gel was divided vertically into 2 parts. One part was stained with silver stain (Bio-Rad Laboratories). The second part of the gel was used for the detection of antimicrobial activity according to Bhunia et al. (1987) after 2 washing cycles with sterile distilled water for $1.5 \mathrm{~h}$ each. The gel was placed into a Petri dish and overlaid with $7 \mathrm{~mL}$ of MRS agar $(0.7 \%)$ containing $10^{6}$ cells $/ \mathrm{mL}$ of the indicator strain L. lactis HP. The dish was then incubated at $30^{\circ} \mathrm{C}$ for $18 \mathrm{~h}$ and examined for inhibition zones.

\section{Prepurification of Bacteriocins}

Bacteriocin-producing strains were inoculated at 1\% and cultured at $30^{\circ} \mathrm{C}$ overnight in $400 \mathrm{~mL}$ of M17 broth (Biolife Italiana S.r.l., Milano, Italy) or reconstituted $(10 \%)$ skim milk. Cultures were centrifuged at 6,000 $\times g$ for $15 \mathrm{~min}$ at $4^{\circ} \mathrm{C}$. Supernatants were filtered through a Whatman No. 2 filter (Whatman Ltd., Maidstone, UK) and sterilized by passage through a Millex $0.22-\mu \mathrm{m}$ HV filter (Millipore). The solutions were loaded onto SepPak $\mathrm{C}_{18}$ cartridges (Waters, Milford, MA). Cartridges
Table 1. Polymerase chain reaction identification and amplification with nisin or lacticin 481 structural gene primers of bacteriocinproducing lactococci isolated from raw ewes' milk

\begin{tabular}{lcc}
\hline PCR identification of Lactococcus lactis & Nisin & Lacticin 481 \\
\hline L. lactis ssp. lactis INIA Z11 & - & + \\
L. lactis ssp. lactis INIA Z101 & + & + \\
L. lactis ssp. lactis INIA Z102 & + & + \\
L. lactis ssp. lactis INIA Z103 & + & + \\
L. lactis ssp. cremoris INIA Z105 & - & + \\
L. lactis ssp. lactis INIA Z106 & + & + \\
L. lactis ssp. lactis INIA Z108 & + & + \\
L. lactis ssp. lactis INIA Z109 & + & + \\
L. lactis ssp. lactis INIA Z110 & + & + \\
L. lactis ssp. lactis INIA Z111 & + & + \\
L. lactis ssp. lactis INIA Z112 & + & + \\
L. lactis ssp. cremoris INIA Z113 & - & + \\
L. lactis ssp. lactis INIA Z114 & + & + \\
L. lactis ssp. lactis ATCC 11454 & + & - \\
L. lactis ssp. lactis CNRZ 481 & - & + \\
\hline
\end{tabular}

were equilibrated with $2 \mathrm{~mL}$ of methanol, followed by $2 \mathrm{~mL}$ of distilled water. The antibacterial compounds were eluted with successive steps of methanol:water mixtures (from 10 to $100 \% \mathrm{MeOH}$ ). Antimicrobial activity in fractions was assayed by the agar well diffusion method, with L. lactis HP and Lb. buchneri St2A as indicator strains.

\section{RESULTS AND DISCUSSION}

\section{Identification of Bacteriocin-Producing Isolates}

Mean counts of LAB in curds made from raw milk samples from 5 different PDO Zamorano cheesemanufacturing plants were approximately $\log 9 \mathrm{cfu} / \mathrm{g}$. Thirteen isolates, which exhibited antimicrobial activity against $L$. lactis HP, were selected. The production of bacteriocin-like antimicrobial compounds was confirmed by the agar well diffusion assay against $L$. lactis HP.

All bacteriocin-producing gram-positive catalasenegative cocci were identified by PCR as L. lactis (Table 1). Eleven isolates exhibited the pattern characteristic of L. lactis ssp. lactis and 2 isolates were identified as L. lactis ssp. cremoris.

The analysis of PFGE patterns of the chromosomal DNA restriction patterns generated by $S m a I$ digestion showed low genetic diversity within this group of lactococci (Figure 1). Pulsed-field gel electrophoresis divided the 13 bacteriocin-producing isolates into 4 pulsotypes (P1, P2, P3, and P4). Lactococcus lactis ssp. lactis INIA Z11 was classified into pulsotype $\mathrm{P} 1$, L. lactis ssp. cremoris INIA Z105 and INIA Z113 into P2, L. lactis ssp. lactis INIA Z103 and INIA Z 106 into P3, and the rest of the L lactis ssp. lactis isolates (INIA Z101, INIA Z102, INIA Z108, INIA Z109, INIA Z110, INIA Z 111, INIA Z112, and INIA Z114) into P4. All isolates except 


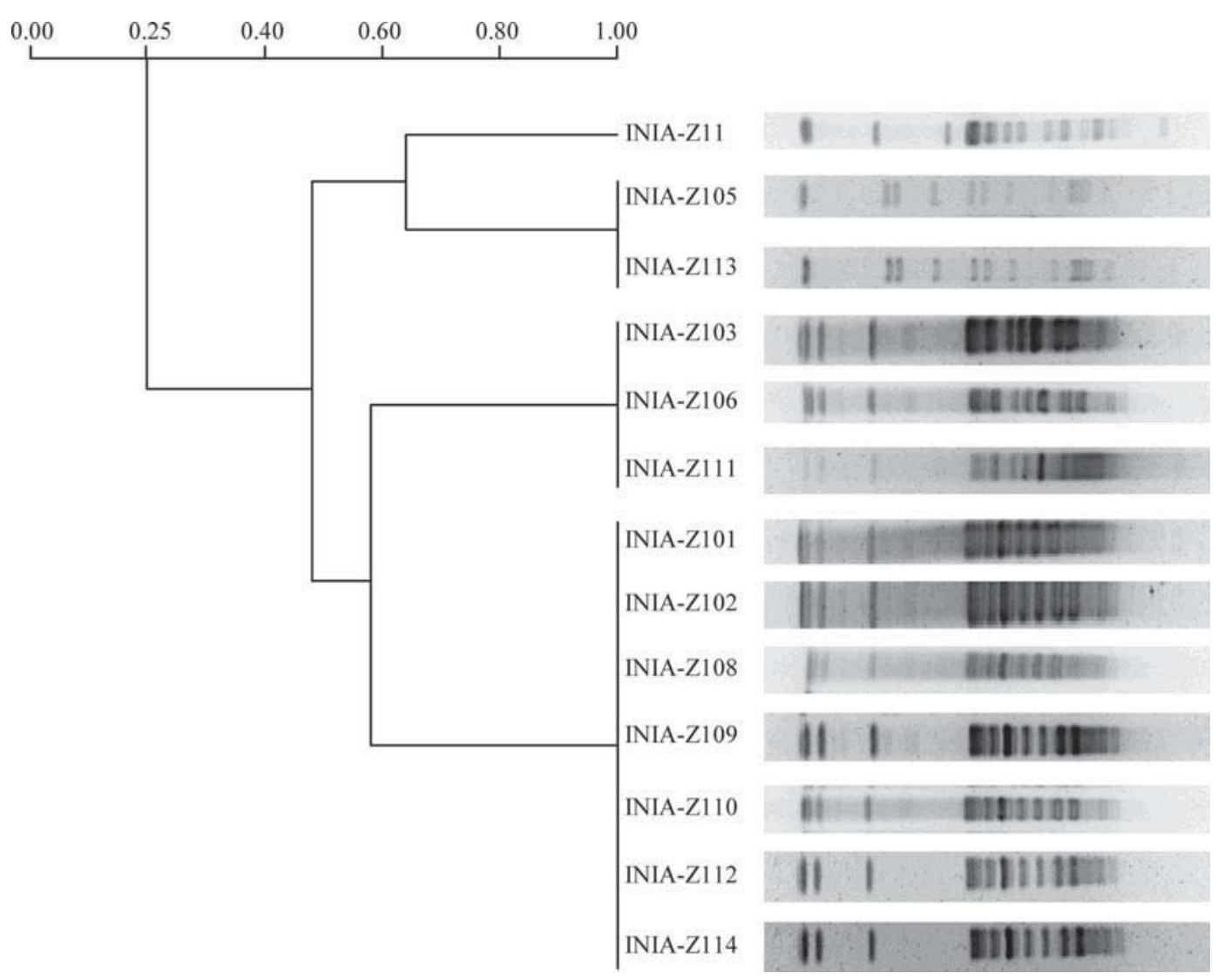

Figure 1. SmaI pulsotypes and dendrogram obtained with 13 isolates of bacteriocin-producing lactococci from raw ewes' milk.

L. lactis ssp. lactis INIA Z11 were obtained from milk from the same cheese-manufacturing plant. The plant makes cheese from milk produced by its own flock of Castellana breed sheep. Good hygiene practices were observed in milk and cheese production.

Lactococci commonly isolated from artisanal cheese varieties mostly belong to the species L. lactis (Cogan et al., 1997), with L. lactis ssp. lactis as the predominant subspecies in many cheese varieties (Nuñez et al., 1989). A high genetic diversity within L. lactis strains isolated from raw ewes' milk cheese was revealed by random amplification of polymorphic DNA analysis (Gaya et al., 1999). Approximately $70 \%$ of lactococci were identified by these authors as L. lactis ssp. lactis, with L. lactis ssp. cremoris and L. lactis ssp. lactis biovar diacetylactis in a lower proportion. Bacteriocin-producing LAB from raw milk have largely been isolated and characterized. Bacteriocin-producing lactococci were the majority among the bacteriocinogenic LAB isolated from raw milk (Rodriguez et al., 2000) and were also common among raw milk cheese isolates (Martinez et al., 1995; Cardinal et al., 1997). The production of bacteriocins provides an ecological advantage that enables producers to withstand competition against other bacteria in milk.

\section{Characterization of Bacteriocins}

Bacteriocins produced by the 13 isolates were characterized by using nisin, lacticin 481 , and lactococcin $\mathrm{A}$ structural gene primers. Deoxyribonucleic acid from 10 of the 13 isolates amplified the expected 898-bp fragment containing the structural gene of nisin (Table 1). Lacticin 481 genetic determinants were detected in the 13 bacteriocin-producing isolates studied. The expected 366-bp fragment containing the structural gene lct of lacticin 481 (Piard et al., 1992) was observed in all the isolates and in the reference strain L. lactis CNRZ 481. Consequently, the structural genes of nisin and lacticin 481 were present in 10 isolates. On the other hand, the structural gene of lactococcin A was not detected by PCR.

The 3 isolates carrying the structural gene of lacticin 481 , but not the structural gene of nisin, were $L$. lactis ssp. lactis INIA Z11, L. lactis ssp. cremoris INIA Z105, and L. lactis ssp. cremoris INIA Z113. Lactococcus lactis INIA Z11 amplified a band of $980 \mathrm{bp}$ with the nisin primers instead of the expected 898-bp band. The sequence of this amplified fragment did not shown homology with sequences of nisin or any other known bacteriocin. The other 2 isolates were those identified 


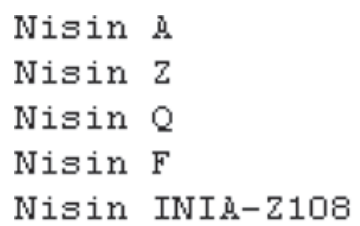

MSTKDFNLDLVSVSKKDSGASPRITS ISLCTPGCKTGALMGCNMKTẢTCHCS IHVSK 57 MSTKDFNLDLVSVSKKDSGASPRITS ISLCTPGCKTGALMGCNMKT ẢCN̄CSIHVSK 57 MSTKDFNLDLVSVSKTDSGASTRITS ISLCTPGCKTGVL MGCNLKTATCNCSVHVSK 57

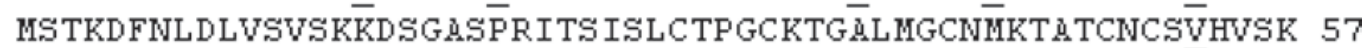
MSTKDFKLDLVSVSKKHSGASPRITSISLCTPGCKTGAVMGCHKTATCHCSÏHVSK 57

Figure 2. Amino acid sequence of nisin from Lactococcus lactis ssp. lactis INIA Z108, deduced from the DNA sequence and compared with the sequences of nisin A, nisin Z, nisin Q, and nisin F. Differences in AA are indicated by underlined letters.

as L. lactis ssp. cremoris, and were classified into the same PFGE group.

Lactococcus lactis ssp. lactis INIA Z108, amplifying for the nisin and lacticin 481 structural genes, was selected as representative of the main pulsotype for bacteriocin confirmation. The nucleotide sequence of the 898-bp DNA fragment confirmed that the bacteriocin produced was nisin. The sequence of the 898-bp band (Figure 2) showed a $96 \%$ identity with the sequence of the nisin Z precursor (Mulders et al., 1991), 94\% identity with the sequence of nisin $\mathrm{A}$ and nisin $\mathrm{F}$ precursors (de Kwaadsteniet et al., 2008), and 87\% identity with the nisin Q precursor (Zendo et al., 2003). Nisins A, $\mathrm{Z}, \mathrm{Q}$, and $\mathrm{F}$ are variants produced by L. lactis isolates from different origins. Nisin Q was detected in an $L$. lactis strain isolated from river water in Japan, and ni$\sin \mathrm{F}$ was detected in the intestinal tract of a freshwater fish in South Africa. In addition, nisin U produced by Streptococcus uberis, which has $78 \%$ sequence identity to nisin A, has been reported (Wirawan et al., 2006). At the AA level, 2 polymorphisms were detected when nisin from L. lactis INIA Z108 was compared with the
AA consensus nisin sequence (Figure 2), asparagine instead of aspartic acid at position $17\left(\mathrm{~N}_{17} \mathrm{D}_{17}\right)$, and valine instead of leucine at position $39\left(\mathrm{~V}_{39} \mathrm{~L}_{39}\right)$. Our results suggest the possibility of a new nisin variant, although both equivalent substitutions are considered unlikely to bring about substantial changes in gene expression. More research is needed for a detailed characterization and analysis of nisin from $L$. lactis INIA Z108. On the other hand, the sequence of the 366-bp amplified fragment from the lacticin 481 structural gene lct $A$ revealed $100 \%$ identity with the corresponding sequence of lacticin 481.

The predominance of nisin-producing lactococci among wild lactococci isolated from raw milk was reported by Rodriguez et al. (2000). These authors also detected the presence of lacticin 481 producers. Recently, nisin genes were detected in DNA from 6 out of 9 Slovenian traditional cheeses, whereas the incidence of lacticin 481 determinants was lower (Trmcic et al., 2008). The presence of genes encoding nisin $\mathrm{Z}$ and lacticin 481 in the same strain has been proven so far only by Garde et al. (2001), in L. lactis ssp. lactis INIA 415

Table 2. Inhibitory activity of methanol fractions ${ }^{1}$ obtained from supernatants of bacteriocin-producing lactococci isolated from raw ewes' milk, cultured in M17 broth or in milk, against 2 selective indicators ${ }^{2}$

\begin{tabular}{|c|c|c|}
\hline Item & $\begin{array}{c}\text { Nisin }(10 \% \text { methanol fraction; } \\
\text { Lactococcus lactis } \mathrm{HP} / \\
\text { Lactobacillus buchneri } \mathrm{St} 2 \mathrm{~A})\end{array}$ & $\begin{array}{c}\text { Lacticin } 481 \text { ( } 70 \% \text { methanol } \\
\text { fraction; Lactococcus lactis } \mathrm{HP} \\
\text { Lactobacillus buchneri } \mathrm{St} 2 \mathrm{~A})\end{array}$ \\
\hline \multicolumn{3}{|l|}{ M17 broth } \\
\hline L. lactis INIA Z101 & $+1+$ & $-1-$ \\
\hline L. lactis INIA Z103 & $+/+$ & $+1-$ \\
\hline L. lactis INIA Z108 & $-1-$ & $+1-$ \\
\hline L. lactis INIA 415 & $-1-$ & $+1-$ \\
\hline L. lactis INIA 626 & $+/+$ & $-1-$ \\
\hline L. lactis INIA 639 & $-1-$ & $+/-$ \\
\hline \multicolumn{3}{|l|}{ Milk } \\
\hline L. lactis INIA Z101 & $+/+$ & $+/-$ \\
\hline L. lactis INIA Z103 & $-1-$ & $+1-$ \\
\hline L. lactis INIA Z108 & $+/+$ & $+1-$ \\
\hline L. lactis INIA $415^{3}$ & $+1+$ & $-1-$ \\
\hline L. lactis INIA $626^{3}$ & $+/+$ & $-1-$ \\
\hline L. lactis INIA $639^{3}$ & $-1-$ & $+1-$ \\
\hline
\end{tabular}

${ }^{1}$ Nisin eluted with methanol at $10 \%$ and lacticin 481 at $70 \%$.

${ }^{2}$ Lactococcus lactis HP is sensitive to nisin and lacticin 481. Lactobacillus buchneri St2A is sensitive to nisin and resistant to lacticin 481 .

${ }^{3}$ Lactococcus lactis INIA 415 has the structural genes of nisin and lacticin 481. Lactococcus lactis INIA 626 and L. lactis INIA 639 are nisin Z and lacticin 481-producing strains, respectively. 


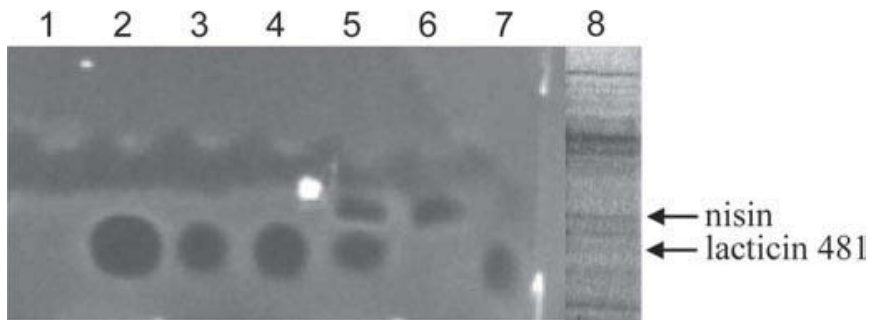

Figure 3. Separation of bacteriocins from culture supernatants by SDS-PAGE and overlaid with de Man, Rogosa, Sharpe agar (Difco Laboratories, Detroit, MI) with Lactococcus lactis HP as an indicator microorganism: 1) negative control, 2) L. lactis INIA Z103, 3) L. lactis INIA Z101, 4) L. lactis INIA Z108, 5) L. lactis INIA $626+$ L. lactis INIA 639,6$)$ L. lactis INIA 626, 7) L. lactis INIA 639, 8) supernatant from L. lactis INIA Z103 after silver staining.

isolated from raw milk Manchego cheese. Interestingly, the simultaneous presence of both genetic determinants had not been observed previously among isolates from raw milk (Rodriguez et al., 2000) or different dairy products, including cheeses (Cogan et al., 1997). In the present work, bacteriocin-producing strains were obtained from curds in which a natural enrichment for bacteria took place. Such isolates predominating in curds might be technologically competitive in cheese making. The 10 isolates with the genetic determinants of both bacteriocins were ascribed to only 2 pulsotypes, a fact that points to their competitiveness.

\section{Antimicrobial Activity}

As indicated previously, supernatants from 10 isolates inhibited both L. lactis HP, which is sensitive to nisin and lacticin 481, and Lb. buchneri St2A, which is sensitive to nisin and resistant to lacticin 481 indicators. Nisin production was thus confirmed in all 10 isolates with the genetic determinants for nisin and lacticin 481. However, lacticin 481 production had to be demonstrated.

Supernatants of bacteriocin-producing L. lactis ssp. lactis INIA Z103, L lactis ssp. lactis INIA Z108, and $L$. lactis ssp. lactis INIA Z114 with the genetic determinants of nisin and lacticin 481 and from L. lactis ATCC 11454 (nisin) and L. lactis CNRZ 481 (lacticin 481) were fractioned by SDS-PAGE. Antimicrobial activities were detected on the gel with the soft agar layer inoculated with the sensitive strains of L. lactis HP (Figure 3). Higher inhibition halos were observed in the presence of supernatants from isolates with both genetic determinants, although individual activities were not separated into the expected 2 bands. When the supernatants of L. lactis ATCC 11454 (nisin) and L. lactis CNRZ 481 (lacticin 481) were mixed at 50\%, 2 halos corresponding to nisin and lacticin 481 were clearly differentiated. Protein bands corresponding to bacteriocins were not easily distinguished on the SDSPAGE gels after staining with silver stain, probably because of the high number of metabolites in the supernatant without further treatment.

After prepurification by Sep-Pak cartridges, the bacteriocins in supernatants were recovered in different fractions. Nisin eluted at 10 to $20 \%$ methanol and lacticin 481 eluted at 70 to $90 \%$, in agreement with the high proportion of hydrophobic residues in the latter. Larger halos were observed for the 10 and $70 \%$ methanol fractions for nisin and lacticin 481 activities, respectively. Activities of these fractions from cultures of 3 isolates in M17 broth and milk, against the 2 selective indicator strains L. lactis HP and Lb. buchneri St2A, are shown in Table 2. Coproduction was confirmed in the semipurified preparations of L. lactis INIA Z101, INIA Z103, and INIA Z108, although it was dependent on the growth medium. The simultaneous presence of nisin and lacticin 481 was observed in the supernatants of L. lactis INIA Z103 grown in M17 broth and in the supernatants of L. lactis INIA Z101 and INIA Z108 grown in milk. As expected, nisin and lacticin 481 were detected in supernatants from L. lactis INIA 626 and $L$. lactis INIA 639, respectively. With respect to the previously studied L. lactis ssp. lactis INIA 415, lacticin 481 was the only bacteriocin produced in M17 broth and nisin was the only one produced in milk. Bacteriocin production can be influenced by environmental conditions, such as the composition of the culture medium, $\mathrm{pH}$, and the temperature of incubation (Gänzle et al., 1999). Differences in bacteriocin production in MRS and milk medium supplemented with yeast extract were reported by Avonts et al. (2004) in probiotic Lactobacillus strains. According to those authors, factors that may contribute to the low bacteriocin titers in milk medium were associated with the adsorption of bacteriocins to $\mathrm{CN}$, the scarce induction of production by medium components, or lower biomass formation. In our work, the undetectable nisin or lacticin 481 activities found in M17 broth or in milk might be attributed to reduced bacteriocin production.

The use of lactococcal bacteriocins as tools to control microbial populations in food systems was reviewed by Guinane et al. (2005). In the present work, L. lactis strains coproducing nisin and lacticin 481 in broth and in milk were obtained. To extend the potential applications for lactococcal bacteriocins, optimization of bacteriocin production by our isolates under industry conditions should be investigated.

\section{CONCLUSIONS}

In the present work, bacteriocin coproduction was detected in new L. lactis isolates from raw ewes' milk. 
The coproduction of nisin and lacticin 481 would constitute a useful system for the biological control of spoilage or pathogenic microorganisms. These new Lactococcus isolates can have a potential impact on the development of new industrially important cultures for their application in the manufacture of dairy products.

\section{ACKNOWLEDGMENTS}

This work was supported by INIA-Fondo Europeo de Desarrollo Regional (FEDER) projects RM01-002 and RM2004-00013-00-00.

\section{REFERENCES}

Avonts, L., E. Van Uytven, and L. De Vuyst. 2004. Cell growth and bacteriocin production of probiotic Lactobacillus strains in different media. Int. Dairy J. 14:947-955.

Beimfohr, C., W. Ludwig, and K. H. Schleifer. 1997. Rapid genotypic differentiation of Lactococcus lactis subspecies and biovar. Syst. Appl. Microbiol. 20:216-221.

Bhunia, A. K., M. C. Johnson, and B. Ray. 1987. Direct detection of an antimicrobial peptide of Pediococcus acidilactici in sodium dodecyl sulfate polyacrylamide gel electrophoresis. J. Ind. Microbiol. $2: 319-322$.

Cardinal, M. J., J. Meghrous, C. Lacroix, and R. E. Simard. 1997. Isolation of Lactococcus lactis strains producing inhibitory activity against Listeria. Food Biotechnol. 11:129-146.

Cintas, L. M., P. Casaus, C. Herranz, L. S. Havarstein, H. Holo, P. E. Hernandez, and I. F. Nes. 2000. Biochemical and genetic evidence that Enterococcus faecium L50 produces enterocins L50A and L50B, the sec-dependent enterocin P, and a novel bacteriocin secreted without an $\mathrm{N}$ terminal extension termed enterocin Q. J. Bacteriol. 182:6806-6814

Cleveland, J., T. J. Montville, I. F. Nes, and M. L. Chikindas. 2001. Bacteriocins: Safe, natural antimicrobials for food preservation. Int. J. Food Microbiol. 71:1-20.

Cogan, T. M., M. Barbosa, E. Beuvier, B. Bianchi-Salvadori, P. S. Cocconcelli, I. Fernandes, J. Gomez, R. Gomez, G. Kalantzopoulos, A. Ledda, M. Medina, M. C. Rea, and E. Rodriguez. 1997. Characterization of the lactic acid bacteria in artisanal dairy products. J. Dairy Res. 64:409-421.

Deegan, L. H., P. D. Cotter, C. Hill, and P. Ross. 2006. Bacteriocins: Biological tools for bio-preservation and shelf life extension. Int. Dairy J. 16:1058-1071.

de Kwaadsteniet, M., K. ten Doeschate, and L. M. T. Dicks. 2008. Characterization of the structural gene encoding nisin $\mathrm{F}$, a new lantibiotic produced by a Lactococcus lactis subsp. lactis isolate from freshwater catfish (Clatias gatiepinus). Appl. Environ. Microbiol. 74:547-549.

Dufour, A., T. Hindre, D. Haras, and J. P. Le Pennec. 2007. The biology of lantibiotics from the lacticin 481 group is coming of age. FEMS Microbiol. Rev. 31:134-167.

Gänzle, M. G., S. Weber, and W. P. Hammes. 1999. Effect of ecological factors on the inhibitory spectrum and activity of bacteriocins. Int. J. Food Microbiol. 46:207-217.

Garde, S., M. Avila, P. Gaya, M. Medina, and M. Nuñez. 2006. Proteolysis of Hispanico cheese manufactured using lacticin 481-producing Lactococcus lactis ssp. lactis INIA 639. J. Dairy Sci. 89:840-849.

Garde, S., E. Rodriguez, P. Gaya, M. Medina, and M. Nuñez. 2001. PCR detection of the structural genes of nisin Z and lacticin 481 in Lactococcus lactis subsp. lactis INIA 415, a strain isolated from raw milk Manchego cheese. Biotechnol. Lett. 23:85-89.
Gaya, P., M. Babin, M. Medina, and M. Nuñez. 1999. Diversity among lactococci isolated from ewes' raw milk and cheese. J. Appl Microbiol. 87:849-855.

Guinane, C. M., P. D. Cotter, C. Hill, and R. P. Ross. 2005. Microbial solutions to microbial problems: Lactococcal bacteriocins in the control of undesirable biota in foods. J. Appl. Microbiol. 98:13161325.

Hanlin, M. B., N. Kalchayanand, P. Ray, and B. Ray. 1993. Bacteriocins of lactic acid bacteria in combination have greater antibacterial activity. J. Food Prot. 56:252-255.

Le Bourgeois, P.. M. Mata, and P. Ritzenthaler. 1989. Genome comparison of Lactococcus strains by pulsed-field gel electrophoresis. FEMS Microbiol. Lett. 59:65-69.

Martinez, B., J. E. Suarez, and A. Rodriguez. 1995. Antimicrobials produced by wild lactococcal strains isolated from homemade cheeses. J. Food Prot. 58:1118-1123.

Mulders, J. W. M., I. J. Boerrigter, H. S. Rollema, R. J. Siezen, and W. M. de Vos. 1991. Identification and characterization of the lantibiotic nisin Z, a natural nisin variant. Eur. J. Biochem. 201:581-584.

Nuñez, M., M. Medina, and P. Gaya., P. 1989. Ewes' milk cheese: Technology, microbiology and chemistry. J. Dairy Res. 56:303321

O'Sullivan, L., M. P. Ryan, R. P. Ross, and C. Hill. 2003. Generation of food grade lactococcal starters which produce the lantibiotics lacticin 3147 and lacticin 481. Appl. Environ. Microbiol. 69:36813685.

Oumer, A., S. Garde, P. Gaya, M. Medina, and M. Nuñez. 2001. The effects of cultivating lactic starter cultures with bacteriocin producing lactic acid bacteria. J. Food Prot. 64:81-86.

Piard, J. C.. P. M. Muriana, M. J. Desmazeaud, and T. R. Klaenhammer. 1992. Purification and partial characterization of lacticin 481, a lanthionine containing bacteriocin produced by Lactococcus lactis subsp. lactis CNRZ 481. Appl. Environ. Microbiol. 58:279-284.

Quadri, L. E. N., M. Sailer, K. L. Roy, J. C. Vederas, and M. E. Stiles. 1994. Chemical and genetic characterization of bacteriocins produced by Carnobacterium piscicola LV17B. J. Biol. Chem. 269:12204-12211.

Rodriguez, E., J. L. Arqués, M. Nuñez, P. Gaya, and M. Medina. 2005. Combined effect of high pressure treatments and bacteriocin producing lactic acid bacteria on inactivation of Escherichia coli O157:H7 in raw milk cheese. Appl. Environ. Microbiol. 71:33993404.

Rodriguez, E., B. Gonzalez, P. Gaya, M. Nuñez, and M. Medina. 2000. Diversity of bacteriocins produced by lactic acid bacteria isolated from raw milk. Int. Dairy J. 10:7-15.

Schägger, H., and G. von Jagow. 1987. Tricine sodium dodecyl sulfate polyacrylamide gel electrophoresis for the separation of proteins in the range from $1 \mathrm{kDa}$ to $100 \mathrm{kDa}$. Anal. Biochem. 166:368-379.

Schillinger, U., and F. K. Lücke. 1989. Antibacterial activity of Lactobacillus sake isolated from meat. Appl. Environ. Microbiol. 55:1901-1906.

Settanni, L., and A. Corsetti. 2008. Application of bacteriocins in vegetable food biopreservation. Int. J. Food Microbiol. 121:123138

Trmcic, A., T. Obermajer, I. Rogelj, and B. B. Matijasic. 2008. Culture independent detection of lactic acid bacteria bacteriocin genes in two traditional Slovenian raw milk cheeses and their microbial consortia. J. Dairy Sci. 91:4535-4541.

Wirawan, R. E., N. A. Klesse, R. W. Jack, and J. R. Tagg. 2006. Molecular and genetic characterization of a novel nisin variant produced by Streptococcus uberis. Appl. Environ. Microbiol. $72: 1148-1156$.

Zendo, T., M. Fukao, K. Ueda, T. Higuchi, J. Nakayama, and K. Sonomoto. 2003. Identification of the lantibiotic nisin Q, a new natural nisin variant produced by Lactococcus lactis $61-14$ isolated from a river in Japan. Biosci. Biotechnol. Biochem. 67:16161619 . 